there was scarcely anything visible-except that I badly needed a shave. The bristles on my face and neck were well over a quarter of an inch long and that shave took me an hour and twenty minutes, but such scar as there was (a three-inch thread) had completely healed.

First the good news, then the bad news. I couldn't open my mouth more than half an inch and, I was told, it would be six months before I could open it fully. At that stage I was able to eat solid foods-as opposed to having liquid foods poured into me through a tube through a nostril-and there's no doubt about it, if you can open your mouth only half an inch then chopsticks are the only possible eating utensil.

Some 10 days after the operation I was told I would be discharged at the end of the week. I was aghast. I didn't want to be discharged. I wanted to stay in that warm womb of a hospital. On the morning of my departure, and at my request, I reported to the accounts section of the hospital to count the cost. I had had, I felt, the kind of operation Americans mortgage houses to pay for. Vaguely, I wondered what would happen when I told them I couldn't pay: would I have to report to the hospital laundry and iron fundoshis for the next 20 years? But the cost, I was told, was $£ 500$, including the operation, all treatment, and the 20-day stay in hospital. If I cared to join the National Health Insurance scheme, however, I need pay only $30 \%$, the balance being paid by the NHI. Furthermore, I could pay off my $30 \%$ over an extended period if I wished. I don't altogether understand an insurance scheme which permits one to insure oneself retrospectively-to insure oneself against getting what one has already got, or had. But who am I . . . ? And the cost of the contributions? About $£ 1$ a month. So $£ 350$ was paid by the NHI, and I paid the balance. Had I spent those 20 days in the least ostentatious of Tokyo's international hotels, it would have cost a great deal more. And at $£ 1$ a month, I calculated that the Japanese NHI would break even with me in the year 2004. But that calculation has already been proved wrong; I have to report to the Tokyo Dental College every fortnight, and the lion's share of the cost of medicine, $x$ rays, and so on is borne by the NHI, so I don't see the NHI breaking even with me even in 2004.

In the four months that have elapsed since the operation, events have unfolded as forecast : my voice is normal; I can't open my mouth to the extent of inserting three horizontal fingers, but can manage two and a half, while the scar under my left jaw is scarcely visible; I still can't put my tongue out more than half an inch, but am saving a lot of money on sticks of rock and ice cream cornets.

But life hasn't altogether been a bowl of cherries: it was two months before I was strong enough to resume work, and there was the day when the maestro thought that the cancer had transferred to the underside of my tongue. His distress was such that I was tempted to put an arm around his shoulders, tell him not to worry and that in any case I was living on borrowed time, but, in the event, $x$ rays showed no justification for his misgivings. Recently, through a Japanese teacher of English literature, I asked in writing how long I would have lived if the cancer had transferred to my tongue, and how much of that time would I have spent in pain ? I received the same answer to both questions, "1-2 years."

Just something else I really didn't want to know.

\section{(Happy New Year) \\ (Accepted 24 Fune 1977)

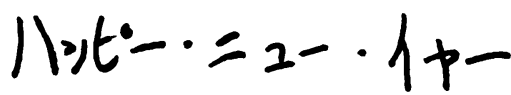

\title{
A case of self-diagnosis
}

\author{
EOIN O'BRIEN
}

\begin{abstract}
"Stately, plump Buck Mulligan came from the stairhead, bearing a bowl of lather on which a mirror and a razor lay crossed. A yellow dressing-gown, ungirdled, was sustained gently behind him by the mild morning air.... Solemnly he came forward and mounted the round gunrest. He faced about and blessed gravely thrice the tower, the surrounding country and the awaking mountains."
\end{abstract}

Ulysses. James Joyce.

It is 6.45 am on a Monday morning. A deep-red sun hovers, suspended, it seems, only a few feet above the calm sea lending to the blue a golden shimmer. The sky is almost clear but the monotony of perfection is gracefully avoided by a scattering of gently drifting pink and grey-white puffs of cloud, which brook no ill to those beneath. The tide is full and adds to the moment a peaceful adagio as the water gently laps the granite and concrete of the shoreline, and the tinkling of the yachts at mooring is accompanied by the musical chatter of numerous

The Charitable Infirmary, Dublin

EOIN O'BRIEN, FRCPI, MRCP, consulting physician birds. I see the cormorants poised with wings spread in statuesque immobility and further out at sea a lone sentinel heron gazes towards the red sky of Howth. The winding sea road from Seapoint to Sandycove is as quiet as a country path; early risers are not plentiful in Dublin and nature undisturbed lavishly evokes a scene of tranquil perfection in the assurance of being unmolested.

My bicycle brings me safely to the Forty Foot. I glance at the ramparts of the Martello Tower, on which an earlier morn would have seen Buck Mulligan and Stephen Dedalus in blasphemous converse. The sign at the entrance to the Forty Foot states in bold freshly painted white on black GENTLEMEN ONLY and as surely as this was painted yesterday it will be blackened by protesting femininity before dusk; an inner notice declares that costumes must be worn after 9 am but at this kind hour the rules of conformity are far from my mind as, undressing, alone I survey the deep sea ahead of me from this rocky paradise. A dive brings the soothing sensation of the cool fresh waters, and nature's wonders seem boundless. I swim a few hundred yards, dive carelessly a few times from the board, and 30 minutes later lying in the sun I am wishing that such moments did not have to cease.

\section{Symptoms}

But the day is Monday, and an hour later walking to the train I am conscious of a nagging pain in my right groin. 
This I dismiss readily as muscle strain due to excessive swimming and cycling in the preceding days, but on the train I realise that I do not feel well, and my newspaper is left unread. Walking along the quays towards the hospital I become more conscious of groin discomfort, but a surreptitious attempt to palpate more accurately through my trouser pocket while coughing in the shadow of the raised arm of the Great Liberator attracts the witty attention of two passing girls, and I postpone further diagnostic manoeuvres. Without enthusiasm I set out on my ward round, and a tendency to perspire is attributed to the warmth of the day.

At the bedside I take every opportunity to lean on the bed or to sit down to make decisions, which are coming very slowly. Then I realise I am going to faint and disappearing as deftly as possible from the bedside group I whisper in passing to staff-nurse that I am not well, and she, acting as though this was an everyday event, escorts me outside to a couch and brings me a glass of iced water. Secure now in the knowledge that the threatened syncope has been averted, I am able to give my anxious senior house officer reassurance that there is nothing seriously wrong and that I have merely contracted a wretched virus infection. I note with some amusement her considerable anxiety and I completely dismiss her gentle suggestions that I might permit a few "simple tests." Being of a determined frame of mind she does not let me go too easily and kindly drives me home in a last desperate attempt to make me see sense by impressing on me how awful I look, and her concern is all the greater because she knows that my family are on holiday. Nevertheless, with the one intention to put as great a distance between myself and my hospital until I have at least diagnosed this malaise, I bolt from her car and kindness and plunge into bed.

\section{Signs}

I awaken some hours later perspiring and after rifling numerous drawers for a thermometer I confirm that $I$ have a fever $\left(38.3^{\circ} \mathrm{C}\right)$. The pain in my groin is now quite severe, and the area is tender to the touch. I have generalised myalgic pains and feel quite wretched. A quick search through the diagnostic files of my mind comes up with nothing better than a saphenous vein thrombosis, and I hastily bury my head in the clouds of sleep.

A bad night. Fever, myalgia, and do I now have meningismus? No, it must be the myalgic pains affecting the cervical musclesyes, almost certainly so. Should I not call someone? Of course, I should, but what if that someone cannot do a better diagnostic job than I ? Perhaps then he would be left with no alternative but to diagnose pyrexia of undetermined origin and saphenous vein thrombosis, and in these circumstances would have no option but to admit me to hospital. Almost certainly he would put me in an intensive care environment, where enthusiastic and well-wishing healers would start me on anticoagulants for the suspected thrombosis, antibiotics (after, of course, lumbar puncture and heaven knows what other diagnostic procedures), and an analgesic or antipyretic for my additional comfort would in all probability potentiate the anticoagulants and I would bleed from God knows where. Perhaps I am becoming delirious. Back to sleep, ay, perchance to dream, rub or no. But the ordered procession of sleep is apt, as Proust put it, "to grow confused, and to break its ranks" and so it was to be. My temperature has now peaked to $39 \cdot 3^{\circ} \mathrm{C}$ and in a vivid nightmare I see a deep-blue thrombus waving like a huge vine in a turbulant river of purple, from the banks of which I watch in helpless horror as the distal tendrils slowly begin to break away from the parent trunk; frantically I throw myself on the log that breaks loose but it is soft and slippery, and I cannot anchor it or myself to the slippery bank, and I am swept along into larger caverns where the purple waters become as rapids, and the roar becomes unbearable; finally the broken vine slips my grasp, and I flounder helplessly in the swirling flood. Then I am awake, perspiring and anticipating the crushing pain of a massive pulmonary embolism. With difficulty I resist the temptation to pick up the telephone.

Then morning dawns and I feel a little better. My groin remains tender and swollen and moving my legs I am aware of a new symptom, pain in the right calf, and with it comes the anguish of a new and more terrible diagnosis-thrombophlebitis migrans. No point in calling anybody to verify this diagnosis: the only question (academic and of no particular consequence to $\mathrm{me}$ ) is the location of the occult neoplasm. Gingerly I draw back the damp bedclothes to inspect the new pathological development and I am surprised to behold a large, raised, and livid area of erythema affecting most of the lateral calf area and in many ways resembling erisypelas. Relieved, I lie back to contemplate this change in my fortunes and am prompted to a closer examination of the groin, which I now realise to be due to inguinal gland enlargement. It all seems so simple-an infection in the leg, a glandular reaction, and then a septicaemia producing the systemic symptoms. But no, this could not be: the sequence is wrong-and even if it were correct, I would not be in a position to contemplate the diagnosis. After all, my first symptom was groin pain, then a systemic reaction, and now 24 hours later a local reaction.

\section{Diagnosis}

I doze for most of the day and my temperature subsides. I feel weak when up. The pain in my calf increases but is superficial and the area of inflammation gradually increases and is of a purple lividity out of all proportion to the degree of discomfort. I am tempted to swallow a fistful of ampicillin, when suddenly in a diagnostic vision I see the older men of the Forty Foot striding naked on the high rocks in warm weather while sceptically viewing the waters beneath before taking their plunge-for the very sound reason that in the brief period when the waters are warm (around $17^{\circ} \mathrm{C}$ ) the Portuguese man-o-war graces our shores. I had seen these formidable brown, long-tentacled blobs on many occasions and had of course avoided them, but my recent practice of swimming well out from shore did not make this possible. The relief of self-diagnosis was considerable. The sting, unfelt while swimming (as often one does not feel injury in salt water), the inoculation with what must be a fairly powerful toxin, a glandular defence reaction, a toxaemia, and then the belated appearance of an erythematous reaction seemed a logical enough explanation. With this reassurance I limped my way to my medical books and read, "Contact with the tentacles of the colourful Portuguese man-o-war (Physalia) species ... is followed by severe pain, swelling, and erythema. Muscle pain, weakness, abdominal cramps, nausea, dyspnoea, cyanosis, and collapse may persist for several days, and fatalities have occurred, sometimes within hours after contact." 1 With relief I call my doctor, not only to impress him with my diagnostic acumen but also to elicit his advice on further treatment.

And what of my progress? Walking was painful for a further four days and I was absent from work for a week. The calf erythema persisted for ten days and the underlying area became considerably indurated, for a time oedematous, and then itchy and scaly; two and a half weeks later there remained slight induration with shiny overlying skin. The glandular reaction persisted for about a week, and it was ten days before I felt fully recovered and nearly three weeks before I cautiously threw myself into Nature's cooler waters, forgiving her almost completely and promising never again to take her too much for granted.

\section{Reference}

${ }^{1}$ Harrison's Principles of Internal Medicine, 6th edn, p 697. New York, McGraw-Hill Book Company, 1970. 